die UVM, wat gedurende die Eerste Werêldoorlog gevestig is, is in die Tweede Werêeldoorlog herhaal : weereens kon hulle slegs in ' $n$ nie-gevegshoedanigheid diens doen. Gleeson versuim egter om aan te dui waarom hulle tóg bereid was om vir oorlogsdiens aan te meld.

Duisende vrywilligers is vanaf 1940 gewerf en het in die Native Military Corps (NMC), die Kleurlingkorps asook die Indian and Malay Services Corps as kokke, wagte, konstruksiewerkers en vragmotorbestuurders, 'n uitstaande bydrae tot die Geallieerdes se oorlogspoging gelewer. In Oos-Afrika en Abessinië bv het hulle tonne voorrade oor lang afstande en moeilike terrein na die voorste lines aangery. In NoordAfrika was hulle die Suid-Afrikaanse Genie behulpsaam om hawens en werkswinkels te beman; paaie, brûe en spoorlyne te bou en in stand te hou; pypleidings te lê en waterpunte aan te bring. En die baardraers op hulle beurt het aan al die verskillende fronte waar die SuidAfrikaanse magte geveg het, onvermoeid en sonder inagneming van hulle eie veiligheid, duisende ongevalle afgevoer. Gleeson se boek bevat ook hoofstukke oor die heldedade, die ontberinge van diégene wat krygsgevangene geneem is asook treffende beskrywings van die waagmoed en deursettingsvermoë wat ' $n$ handjievol wat uit die krygsgevangenekampe ontsnap het, aan die dag gelê het.

Die eise van die oorlog en die gebrek aan mannekrag het teen die einde van 1942 die militêre owerheid genoodsaak om nie-blanke dienspersoneel tot sekere geselekteerde eenhede toe te voeg om nie-gevegsposte in hierdie eenhede te vul ten einde blanke soldate vir die front vry te stel. Slegs in uitsonderlike gevalle is nieblanke dienspersoneel in ' $\mathrm{n}$ gevegsrol opgelei, soos die lede van die Kaapse Korps wat as artilleriste opgelei is en op Madagaskar in 6 Veldregiment gedien het. Hulle het egter nie die geleentheid gekry om aan die beperkte operasies op die eiland deel te neem nie.

Anderkleuriges het nie net in die Leër nie maar ook in die Lugmag en die nuutgestigte Vloot 'n bydrae gelewer. In die Lugmag bv het hulle grondbeskermingsdienste verrig en in die Vloot het hulle die vaartuie se ondersterkte bemannings aangevul. Nie-blanke dienspersoneel het hulle ook aan die tuisfront onmisbaar gemaak met die beskerming van sleutelinstellasies.

Gleeson sluit sy boek af met ' $n$ epiloog waarin hy die nie-blanke dienspersoneel se ontnugtering met die karige vergoeding wat hulle na die oorlog ontvang het, beskryf. Dit is egter verblydend dat dié oudstryders se verbintenis met veterane-organisasies sekere voordele vir hulle meegebring het en dat alle oudgediendes se pensioene sedert 1987 gelyk gemaak is.

Dit outeur het sy onderwerp deeglik nagevors en die beskikbare amtelike argiewe en sekondêre bronne goed benut. Die publikasie is tegnies goed versorg en is keurig met kaarte en toepaslike foto's toegelig. Dit is duidelik dat die outeur moeite gedoen het om geskikte foto's te bekom en dat hy sy finale seleksie met oorleg gedoen het. Aan die einde van die boek verskyn ook ' $n$ nuttige aanhangsel met die name van diegene wie se heldhaftige en buitengewone diens gedurende die Tweede Werêldoorlog, met medaljes vereer is.

L. Jooste, Dokumentasiediens, Privaatsak X289, Pretoria 0001.

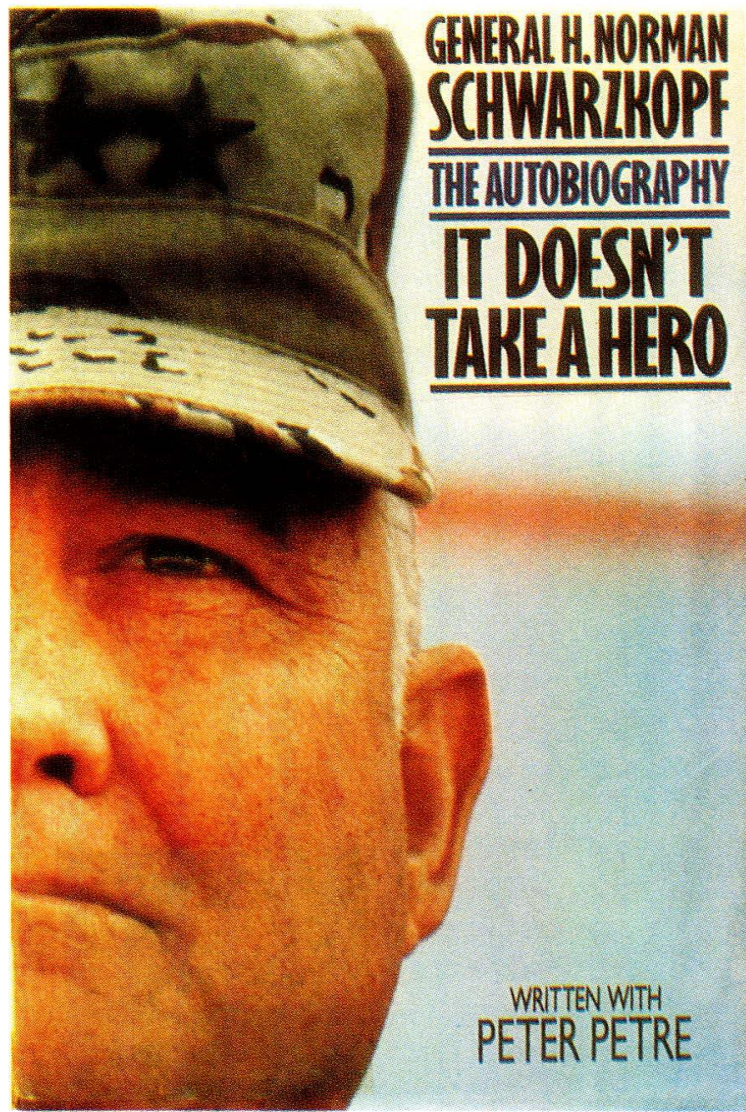

IT DOESN'T TAKE A HERO; GEN H. NORMAN SCHWARZKOPF - THE AUTOBIOGRAPHY

Gen H. Norman Schwarzkopf with Peter Petre

Linda Grey Bantam Books: 1992 ISBN 0-553-08944-7

pp.503

Illustrated

The Gulf War of 1991 was possibly the most mesmerising military conflict of recent times. In a world charged with violence, this particular war somehow stood out and captured the pub 
lic's imagination. This can be attributed to a number of factors, the most important being the fact that leading western powers participated in Operation Desert Storm. Along with this they deployed an enormous range of sophisticated and hi-tech weaponry in the Persian Gulf adding a new dimension to the clash which became impossible to ignore. The disproportionately high media profiles of Desert Shield and Desert Storm was due to the role played by television. For the first time audiences around the globe were able to watch the war unfolding live in their living rooms courtesy of expanding technology and 24 hour news networks.

The most outstanding military personality to emerge from the crusade was without a doubt the Commander in Chief of the Coalition forces, General H. Norman Schwarzkopf (better known in some circles as 'Stormin Norman' or 'the Bear'). Much like two of his famous predecessors, Generals Patten and Bradley, whose names are synonymous with World War Two Schwarzkopf is immediately coupled to the Gulf War. Due to his resounding victory in the Persian Gulf he has emerged as one of the celebrated military men of the late twentieth century and this biography has been long awaited by military enthusiasts the world over.

The main focus of Schwarzkopf's biography falls undeniably on military matters. It is invariably fascinating to examine the early days in the career of a great commander, to attempt to discern what he did differently to his peers. Schwarzkopf, it seems, was surprisingly ordinary, although an above average student, he graduated forty-third in his class at West Point, which while a decent position did not indicate that he would one day rise to the rank of a four star general. However, after leaving the U.S. Military Academy for his first posting with the 101st Airborne Schwarzkopf came into his own. During his two tours of duty in Vietnam, he was considered to have been exceptional. Perhaps the key to his success lay in his work ethos, he never viewed his active duty tours as just another step up on the ladder to his next promotion. On closer inspection he is, in fact, not the archetype of the typical American general at all and throughout this biography a picture emerges of a tremendously complex individual. For instance while he is a great infantryman Schwarzkopf is a man of culture as well, therefore belying the myth that all good soldiers are boorish.

It is arguable that had another officer been appointed to command the U.S. war effort in the gulf that the operation may well not have been as smooth or as successful. With regards to the latter assumption it is well known that Schwarzkopf refused to committ his troops to battle before they were properly trained and equipped although he was under tremendous pressure from the White House to launch Desert Storm for almost six weeks before he actually did so. In so far as American-Arab relations are concerned, Schwarzkopf handled the deployment of the huge western contigent very diplomatically, no mean feat in a muslim fundamentalist country. To understand General Schwarzkopf's unique and successful approach to the Saudis one should be acquainted with the details of his childhood. His father, Herbert Schwarzkopf was also a military man, and during the Second World War, served as the U.S. Attaché in Teheran. Young Norman lived in Iran with his father where he became quite well acquainted with Islamic and desert culture. Consequently on his return to the Middle East some fifty years later he was probably better suited to commanding the Coalition forces there than any other general in the U.S. Army. He was also ideal for the job of liaising with his European counterparts in Saudi Arabia, as he had attended school in Switzerland and Germany as an adolescent and speaks both French and German fluently.

On the subject of his youth and childhood, Schwarzkopf is frank if not blunt. The spotlight falls largely on his father who led the Lindbergh kidnapping investigation and later attained the rank of major general in the U.S. Army. His mother's alcoholism is also a recurring theme throughout the book although this does not lead it to subside into oppressive reading. On the contrary there are many passages which are really entertaining. Schwarzkopf has been blessed with the rare ability to laugh at himself and describes, in vivid detail, some of the funnier sides of his life.

With regard to his military career, It Doesn't Take a Hero provides a full blooded account of General Schwarzkopf's experiences in the Army starting with his entry into the U.S. Military Academy at Westpoint, through two tours of duty in Vietnam and onto his career finale in Saudi Arabia. Schwarzkopf does not bother to conceal his dislike of politicians and he gives a revealing account of the struggle between the Armed Services and the Bush administration over how and when the war should have been fought. General officers who commanded divisions in the Gulf are not forgotten either, the biography provides sometimes scathing assessments of American performances during both Desert Shield and Desert Storm. To his credit the writer refrained from appraising the non-Americans in the coalition forces, although 
an exception to this rule were the Saudi Arabian government and military command. The numerous problems encountered between the Americans and the Arabs, particularly of a financial and cultural nature, are discussed quite openly.

It Doesn't Take A Hero is bound in a hardcover and protected by a dustcover which portrays one side of Schwarzkopf's face taken from a frontal view. The book itself is well illustrated with a number of black and white photographs taken from both family and official collections. A number of maps from the Vietnam and Gulf Wars have also been included and can easily be located as there is a List of Maps in the front of the book. A comprehensive index is also provided at the back of text, thereby enhancing the book's research value. Personal memoirs obviously provide the primary source of information for any biograhpy as is the case with It Doesn't Take a Hero, however a select bibliography also appears at the back of the book. In addition, Schwarzkopf has made some use of war diaries, particularly those of the GHQ during Desert Operation.

While the detail in the book is quite intensive, on the whole it does not become too unwieldy. The early chapters, in particular, make for light reading while the latter half of the book is the source of all the privileged information. Schwarzkopf is generous with his praise and criticism alike and freely offers his opinion on just about everything and everyone who was connected to Desert Storm, thereby ensuring that the book is not a dry run and, more importantly, that it contributes something new to the broad historical debate. It is extremely readable biography which offers a bird's eye view of the experiences of the CINC in the Middle East and should be an indispensable source of information for the serious student of contemporary warfare.

N.M. Cowling, Directorate Documentation Service, Private Bag X289, Pretoria, 0001.

\section{THE FUTURE SOUTH AFRICA; ISSUES, OPTIONS AND PROSPECTS}

\author{
Carel van Aardt \\ ISBN 062701987 \\ J.L. van Schaik \\ 1994 \\ R 42.50
}

Dr Van Aardt is ' $n$ senior lektor aan die Universiteit van Pretoria, verbonde aan die Departement Sosiologie. Hy is hoofsaaklik betrokke by die aktiwiteite van die Sentrum vir Bevolkingstudies. Hy was voorheen adjunk-direkteur by die Nasionale Mannekragkommissie waar hy aan die hoof van die seksie Arbeidsverhoudinge gestaan het.

Dr van Aardt het twee doktorsgrade, $\mathrm{nl}$ in Industriële Sosiologie en Besigheidsadministrasie. Die Universiteit van Pretoria het in 1984 akademiesie erekleure aan hom toegeken.

Hy het reeds verskeie artikels gepubliseer en het ook al 'n wye verskeidenheid gehore toegespreek. Hy spesialiseer in arbeids- en ontwikkelingsnavorsing.

Die skrywer het die stof wat hy wou aanbied logies gekonstrueer en die boek is in nege hoofstukke verdeel. Elke hoofstuk is in die afdelings issues, options en prospects onderverdeel. Die hoofstukke volg logies op mekaar, beginnende by die "wortel van die kwaad" apartheid. Die volgende sake word per hoofstuk behandel:

Apartheid and the legacies of apartheid.

The growing population.

Education and training.

The labour market.

Economic growth and economic development.

Black advancement and affirmative action.

The role of a democratic government.

Social and welfare problems.

An overview of issues, options and prospects for the future South Africa.

Die boek is bevat van ' $n$ bronnelys en ' $n$ indeks.

Die outeur konstateer in die inleiding tot die eerste hoofstuk wat sy doel met die skryf van hierdie boek was, $\mathrm{nl}$ om in die konteks van die "keuses" vir die toekomstige Suid-Afrika, die verskillende opsies te bespreek. Verder, om in die lig van die huidige tendense in Suid-Afrika met betrekking tot wetgewing en beleidsformulering ' $n$ holistiese oorsig van die vooruitsigte vir die toekoms van die land daar te stel.

Dr Van Aardt gee in die eerste hoofstuk een ' $n$ beknopte geskiedenis van die stelsel van apartheid en meld oa:

"The basis of apartheid may be ascribed to British colonialism in South Africa. In 1913 the Native Land Act was passed which allocated certain permanent housing areas to blacks and prohibited the possession of land outside such areas. Following this, the Black Urban Areas Act of 1923 prohibited the permanent settlement of Blacks in "white" areas. These acts laid the groundwork for the National Party (who 